\title{
PULA AND LITERATURE (A Description of a Possible Diachrony)
}

\author{
Vjekoslava Jurdana, Ph.D. \\ Department of Educational Sciences, \\ Juraj Dobrila University of Pula (Croatia) \\ e-mail: vjekoslava@hi.t-com.hr \\ Korina Fabris, \\ Senior Undergraduate in Teaching Studies \\ Juraj Dobrila University of Pula (Croatia) \\ e-mail: kfabris@gmail.com \\ Karmen Legović, \\ Senior Undergraduate in Teaching Studies \\ Juraj Dobrila University of Pula \\ e-mail: karmen.legovic@gmail.com
}

\section{Su m m ary}

The starting point of the paper is the teacher's task to foster the literary heritage of the environment where they live and/or work. In order to realise that, teachers must be constantly informed of the literary achievements of the actual environment.

The authors present a potential description of the literary diachrony of the environment of Pula, highlighting its significant points, accenting the need for permanent composition of this magnificent mosaic.

Key words: literature, Pula, history, teacher, reception of a literary work

\section{Introduction}

Teachers of primary education, amongst other things, have the honourable duty to teach the youngest generations of students how to receive literary works of art. Such a complex task undoubtedly comprises encouragement and development first of personal and then students' awareness of belonging to a concrete cultural environment - in this case the Istrian, the Pula one. It also comprises encouragement and development of the love and respect towards its literary tradition and its authors. 
For this purpose the teacher must be (permanently) informed and aware of the literary life and the heritage of the environment where one lives and works. This will considerably contribute to the quality and achievements of his/her work with the students.

The goal of this paper is to present in a synthetic-analytical manner an outline of a potential diachrony of the literary history of the city of Pula. At the same time important points of such development should be marked offering direction to everyone meeting the literary heritage of Pula. This heritage is, indeed, the most exposed part of literature on the Istrian peninsula and as such its integral part.

Moreover, the intention is to show and to disclose some problematic issues which emerge during such a diachronic re-construction, concerning mostly the relationship between writing history and writing literature.

The development of the Pula/Istrian literature and its thematic-motivic, notional but also formal layers, were (also) affected by the complex history of the area, where many masters ruled and varied cultures, languages and ideologies met. The area is the southern edge of Central Europe, a liminal microspace where cultures and nations come together. This microspace (also) shares the fate of its wider context. Central Europe, being a region stripped of hierarchy has no strictly defined geographical/historiographical features, thus revealing a pronounced fluidity and hardly determinable character. In its vagueness, which includes numerous and various nations, cultures, colourful minorities, liminal meeting points, the Central European area becomes subject to different adoptions which, depending on the current social, historical and political constellations, comprise it in the form of external interventions. Such circumstances point to the existence of a historical (post)colonialism of a special, Central-European type reflected in the experience of uncounted historical and political intrusions which, paradoxically, make a (only) constant in the definition of the term Central Europe. (Petković, 2003) In this context, the important elements are (i) those which were objects of such colonial dynamics which, as Milan Kundera would say, represent a 'distorted' picture of history: the Central-Europeans themselves. Their position of witnesses of history has become the source of their culture, their wisdom, the "frivolous spirit" mocking highness and glory. (Kundera, 1985, 299) Their national literatures speak of colonial life conditions caused by a permanent presence of various masters. It is about experiences of authors - historians who personally witnessed and/or were victims of sudden and mostly unforeseeable regional changes. An important topos of worlds thus created, as areas of meeting and memory, reality and fiction, is the neuralgic nodes seen as unwanted, abrupt and uninvited intrusions of imposed history where private/intimate spheres of an individual(s) are entrapped. This puts problematisation of history and/or the "truth" in the centre of their authors' testimony, whereupon dichotomy of history and literature is cancelled.

The point in question is about individual literary-historical imaginations which include and centre exactly those details marginalized or completely excluded from their discourse by historical records in their "objectivity". Authors belonging to the Central European region, such as Franz Kafka, Italo Svevo, Robert Musil, 
Miroslav Krleža, Czeslaw Milosz, Nedjeljko Fabrio, Claudio Magris and others, have created imaginary worlds based no more on strict differences between connotation and denotation as the basis of distinguishing poetry from historiography. In thus created spaces of 'arbitrary' truth, the meaning is not created on the border but at the point of meeting between notions of poet and historian. Central European writers/historians, by placing their expression into imaginary spaces which 'require' that dichotomies fiction/reality, language/words, word/thing cease to be treated as dichotomies, create a specific notional-discourse space of aesthetic representation given as a kind of discontinuity as opposed to the widespread (west-centric) comprehension on the linear course of stylistic and historical periods. ${ }^{1}$ This is about polyphonic articulations of imaginary spaces meeting points between fiction and reality (literature and history) founded on personal experience. These point to the necessity to (re)construct the complex history of the region. It is also the space, not just time, what is created, the subject of imagination. It becomes the setting of a complex relationship between essential parts of human existence: language, history and environment - in words, discourse in process.

By contextualising such complex relations between writing history and writing literature, we will follow the development and particularities of the literary expression of Pula/Istria. We are not interested simply in the development of this literature, but also in the way the literature of Pula (re)interpreted the context in which it was created, what perspective, or eventually, what testimony it can offer us.

\section{Body}

Pula is one of the many classical cities of the Mediterranean whose beginnings are shrouded by a veil of cryptic mythical conceptions of the Greek age. These are the data belonging to the mythical geography whose roots extend back into the oldest age of the oral folk creation, before the appearance of literacy, when the story of the Argonauts appeared. All known mythical data on the Istrian area, and Pula, of course, are linked to this story (Križman, 1979, 13). It is thus mentioned that Pula was founded by fugitives (Argonauts) from Colchis. From these sources and from the records of the geographer Timaeus the poet Callimachus of Cyrene drew inspiration and then elaborated the data on the genesis of the city of Pula and

\footnotetext{
${ }^{1}$ Aleksandar Flaker $(1986,61)$, in his famous theoretical model of development of stylistic formations, observes that "correlation between supranational stylistic formations and individual national literatures renders a special issue when we betake to study those literatures that developed, if we accept Krleža's identification, east of the Gdańsk-Trieste line." Having noticed an aporia about the denomination/definition of the region and explaining that this is actually a complex of central and eastern Europe and not an east-European area, Flaker points out that the literatures of this area create a particular literary and historical unity, conditioned mainly by affine historical reasons, for example the invasions of the Tatars and the Turks, and the long domination of language cultures which "slowed down or interrupted the development of national cultures that we know from the cultural and historical models created by the leading literatures of western Europe."
} 
of its name. In his fragment on Pula, containing only two elegiac couplets, he is the first to form the legend on the genesis of Pula in a poetic way:

"Na Ilirskoj rijeci smiriše vesla, Pored grobnoga kamena plavokose Harmonije-Zmije; Grad utemeljiše: Grk bi mu neki rekao - " Grad Bjegunaca", no njihov ga jezik imenova Pulom."

(Križman, 1997, pp. 42 - 44)
"Some by the Illyrian waters stayed their oars and beside the stone of fair-haired Harmonia, become a snake, they founded a town, which a Greek would call the city of Exiles, but their tongue named it Polae."

(Mair, 1921, p. 301)

This myth was also repeated by the authors of the Roman period: Strabo, Pomponius Mela and Pliny who firmly connected the legend of the Colchian city on the Adriatic with the historical Istrian Pula.

However, when the antique news is collected and compared, one can notice that there are two Pulas on the Adriatic. One of them is the mythical city of Pólai, which was imagined somewhere in southern Illyria, probably where today's Ulcinj is located. The other one is the historical Istrian Pula which was mentioned by the above listed Roman authors for its being a well-known roman colony. However, due to the similar name, many confusions and identifications of these two cities have occurred.

The period of Pula's history was given a literary and artistic form by (i) Stjepan Vukušić. ${ }^{2}$ In his novel Duh u kamenu he depicts the ancient Roman Pula Pietas Iulia and describes the construction of the Amphitheatre.

In the Migration Period Slavs and Croats began to settle the wider surroundings of Pula in the $7^{\text {th }}$ century. In 1331 Pula finally succumbed to the rule of Venice, but the Venetians did not show any interest in the economic development of Pula as a city. They were only interested in its port which was used as a transit point on the way from Venice towards the Levant. From the $16^{\text {th }}$ century on, frequent epidemics of plague, the endemic malaria and other diseases drastically diminished the inhabitants so that at the end of the $17^{\text {th }}$ century Pula had a population of approximately 600 people. Nevertheless, from the periods of Humanism and Renaissance the European cultural public came to know Pula through its ancient heritage, which was very popular at the time. Numerous drawings and drafts of Pula's ancient monuments, such as the Amphitheatre, the Arch of the Sergii, the Temple of Augustus, appeared. Following the collapse of Venice, Istria and Pula were assigned to the Austrian crown. From 1815 until the end of the First World War Pula was part of the Austrian Littoral (Küstenland). When the Arsenal, i.e. the main naval base of the Austrian Navy, was opened in 1856, development of the

\footnotetext{
${ }^{2}$ Stjepan Vukušić was born in 1931 at Stinica near Senj and has lived in Pula since 1965. He writes scientific (philological) and literary works. In the context of the topic of this paper we would highlight Vukušić's novels: Admiral: roman o Janku Vukoviću pl. Podkapelskom, prvom hrvatskom admiralu (2004), Duh u kamenu (1997), Zvijezde nad Gočanom (2003)
} 
modern city and thus of the whole of Istria began. In 1876 Pula was linked by railway with the important line operating between Vienna and Trieste. This brought tourist prosperity to the city and the nearby Brijuni islands, especially after the stay of the whole imperial family headed by Franz Joseph in Pula.

The complex history of Pula, marked by the continuing change of rulers, became particularly turbulent in the twentieth century. This century was the scene of many changes of government which saw the departure from Pula of one party, the arrival of other parties from various corners, their stay and again departure. Some would return, some remained. Such an exchange was specifically caused by the two World Wars. The end of the First World War in Pula was signalled by (i) a historical event - the sinking of the ship Viribus Unitis. This historical landmark was depicted in literature by the previously mentioned Stjepan Vukušić in his novel Admiral. The main character of the novel is Janko Vuković pl. Podkapelski (an actual historical figure, the first Croatian admiral) whose life story unfolds in a wider framework of historical incidents. The novel is about the collapse of the Monarchy when the naval port of Pula became the scene of a tragic event - the sinking of a famous flagship Viribus Unitis. Hundreds of innocent people, who would never see the desired freedom, drowned in this tragedy. Even the main character Vuković chose to end his life on the sea bed off Pula - among his people.

This period of Pula's history was also marked by a remarkable memoiristic and essayistic prose Puna je Pula by Mijo Mirković - Mate Balota. ${ }^{3}$ This work was printed in 1954 and appeared in the Croatian literature at the time when operas of other authors were being published, authors whose artistic alibi was hidden in the impact of the real. ${ }^{4}$ Namely, (i) Balota's Puna je Pula proves that there exists a recognizable and rarely complete artistically sublimed link between the typology of the novel and the social issues of a certain milieu and historical period. Balota thus depicted in both a documentary and fictional way the circumstances of Pula during the Austrian rule and immediately after the First World War.

The period of Pula's history between the Two World Wars (italianisation, hardship of the Croatian people in Istria) seen from a nonfictional point of view can be learned from the book Fašizam krstitelj i palikuća written by Hrvoje Mezulić. ${ }^{5}$ The book was published in 1946 and then republished in 1997. In it, based on documents, Mezulić interprets methods and results of italianisation of Croats and

\footnotetext{
${ }^{3}$ Mijo Mirković, pen name Mate Balota (Rakalj, 28. 9. 1898 - Zagreb, 17. 2. 1963), was an economist and writer. His most important work of fiction is the collection of Chakavian poems Dragi kamen (1938) installing him as the leading name of the (Istrian) Chakavian lyrics of the $20^{\text {th }}$ century. His only novel is Tijesna zemlja. Roman iz istarskog narodnog života (1946). He was buried in his native Rakalj where the meeting of Chakavian authors has been held every year since 1968.

${ }^{4}$ For example, the historical novel Danuncijada by Viktor Car Emin or the most complex work in the genre Zastave by Miroslav Krleža.

${ }^{5}$ Hrvoje Mezulić (Pula, 22. 11. 1901 - Zagreb, 9. 4. 1977), publicist and attorney, scholar and polyglot. After 1945 researched war crimes committed in Istria and studied the archives of the Fascist police.
} 
Slovenes on the territories that belonged to Italy after the First World War. This data clearly tell us that the border/limes was often a violent region where One (the coloniser) would empower himself to be the master of the Other (the colonised), demanding that the only and unquestionable truth be the one he as the unquestionable master prescribes. Nevertheless, at the limes (and not only there) every discriminatory and dictatorial endeavour is broken against the waves of history and space. Even though heavily destroyed during the Second World War raids, in the second half of the $20^{\text {th }}$ century Pula redevloped and flourished into the largest Istrian city, important for its two major economic activities: industry, headed by shipbuilding, and tourism.

The post-war period, in particular the times immediately after World War 2, were discussed by Milan Rakovac ${ }^{6}$ in his own literary way. In his most popular piece Riva $i$ druži he presents the period between 1945 and 1947, namely the transitory period in this area when the state and political conflicts concerning the division of the (Istrian) territory had not yet been resolved. Through forty brief prose works, connected by the character of a boy named Grgo, he gives a picture of the time when the traumas of the Fascist terror were still fresh and the two-year AngloAmerican occupation kept the local people in uncertainty.

The period from the 1960's onwards, in particular the period of the Croatian Spring political movement in Istria - Pula, is the subject theme of the novel Zvijezde nad Gočanom written by Stjepan Vukušić.

It seems that the 1980's were rather productive when it comes to literature in Pula, whether Pula was thematised literally or indirectly. This is witnessed by varied author's approaches, from the book Via Pula by Dragan Velikić to Antun Milovan and his collections of poems (1986 Suhozidi, 1987 Svečanost gromača, 1988 Onkraj Kamenjaka and 1989 Odrazi).

What must be emphasized at this point is the work of Danijel Načinović whose opus goes beyond the framework of the regional, native context, even though his native country is the fundamental subject-thematic but also expressive framework. Today Načinović is one of the leading contemporary Croatian poets. He was born in Labin in 1952 but lives and writes in Pula. As a poet, storyteller, translator and journalist he is an author of an extremely rich and varied opus, which comprises even children's books. For example, Poluotok snova, songs and short fairy tales for children (Pula, 1983) and Moj tata brodograditelj, songs and sketches (Pula, 1986). ${ }^{7}$ In the context of the Pula topic, Načinović is the author of essays in

${ }^{6}$ Milan Rakovac was born in 1939 at Rakovci near Poreč. Poet and prosaist. member of a number of editorial boards (editions "Istra kroz stoljeća", magazines "Istra" and "Nova Istra"). We would highlight some of Rakovac's titles: "Priko Učke" (poetry, essays, travel piece, records), 1980,"Riva i druži ili, caco su nassa dizza" (novel), 1983 [i. e. 1982], and the second, modified edition, 1984, Istragram: štorije i uganke (short stories), 2000, "Cha for kids", 2004.

${ }^{7}$ In addition there are Čarobna harmonika, fairy tales and stories for children (Pazin, 1995), Jadao se jedan mačak, poems for the youngest (Pazin, 1996), Burrra, picture book (Buzet, 1997), Una, povedi i mene, picture book (Pula, 1998) Belarmin, nebeski jahač, poems and fairy tales (Šibenik, 2001), Sretan Božić, Sybil, fairy tales (Zagreb, 2001). 
photo-monographs Pula sa starih razglednica (Pula/Zagreb, 1988), Istra, terra magica (Zagreb, 1993), Pula (Pula, 2000), Istra, veliko srce Jadrana (Pula, 2000). He edited the text for the book Priče iz Istre, a selection from the works of the $20^{\text {th }}$ century Croatian storytellers (Pula, 1999). ${ }^{8}$ Worth emphasizing is his lyricised prose text, more precisely a long essay Odsjaj zlatnoga runa which has the history of Pula as its topic. There is a certain ambient link of Načinović's text and Balota's book Puna je Pula, but Načinović never leaves the pure sphere of literature.

The last decade of the twentieth century bore plenty of fruits for the literature of Pula. Apart from establishing the magazine "Nova Istra", Boris Biletić published the collection I ča $i$ što i kaj (panorama suvremene hrvatskoistarske lirike) in 1997, and the collection Radovi na nekropoli a year prior to that.

In these years the fellow of the Croatian Academy Josip Bratulic published three books of his own treatises which were all related to the Istrian/Pula region. These are: Istarske književne teme (1987), Sjaj baštine (1990), lzazov zavičaja (1990). The first years of the $21^{\text {st }}$ century saw the arrival of two more books: Istra zavičaj starina i ljepota (2000) and Pula oduvijek (2001). The previously mentioned Boris Biletić published his papers on the Istrian/Pula literary scene - in 2002 his collection of studies, essays and reviews on the contemporary Croatian literature in Istria Glasi književne Istre was published.

To give a summary account, we can say that within the cultural ambiance of Pula, since the 1960's, we can distinguish a few literary generations. The authors belonging to the older generations are: Tatjana Arambašin, Ante Dabo, Stjepan Vukušić, Miroslav Sinčić, Rudolf Ujčić, Milan Rakovac and others. Those who belong to the middle generation are: Daniel Načinović, Tomislav Milohanić, Boris Biletić, Edo Budiša, Goran Filipi, Antun Milovan, Nada Grubišić and others. The younger generation comprises Igor Grbić, Natalija Grgorinić, Ognjen Rađen, Tatjana Gromača, Vlatko Ivandić, Tijana Vukić Stjelja, Evelina Rudan, but many more are being established.

The productive complimentary reality of the literary life of Pula's milieu is also the continuous existence of literary magazines in the Croatian language which have been/were published here since 1950 until today. These are: "Istarski borac" / "Ibor"', "Istarski mozaik", "Istra" and "Nova Istra" and the annual and regional journal "Jurina i Franina" which was published in Pula in separate editions in the Croatian, Italian, Slovene and German languages. Magazines for the young were also published in Pula: "Glas mladih", "Polet", "PET". All this was accompanied by

${ }^{8}$ To illustrate the immersion of Načinović into the Pula's imaginary context, we highlight the fact that he wrote the famous balladic and ironic poem Patrizia, better knon as Addio, Pola set to music and performed by Franci Blašković and Gori Uši Winnetou.

${ }^{9}$ The core of the magazine was a secondary school newspaper - a periodical of the literary section of the "Branko Semelić" Secondary School. Already the first issues of the "Istarski borac" (1953) triggered a discussion on the educational system reform, which can be seen from the titles of the articles: Bum u razredu (Bang in the Classroom), Otvorimo vrata đačkoga doma (Let's open the door of the students' dorm), Vrisak trube (Scream of the Trumpet), O nekim problemima iz škole (About some school problems). 
a publishing activity which showed and disclosed the literary vitality of Pula and the vitality of its authors as a number of serious publishers have been active here publishing books both demanding technically and for their contents. Worth mentioning is the edition "Istra kroz stoljeća" established by the Čakavski sabor founded by Zvane Črnja. ${ }^{10}$ The edition was established with a view to examine the entire literary and culturological history of Istria. Also, since 1990, the Istrian branch of the Croatian Writers' Association has been remarkably active developing a varied publishing and programme business. The event $\mathrm{Sa}(\mathrm{n}) \mathrm{jam}$ knjige u Istri Dreamlike Book Fair in Istria ${ }^{11}$ commenced in 1995 and has now become a wellestablished event. Also worth mentioning is the Pula Essay Days, an international literary and cultural event which has been organised by the Croatian Writers' Association and the magazine Nova Istra since 2003. ${ }^{12}$ We would also mention the Istrian Literary Colony "Grozd" (founded by Aldo Kliman in 1986).

When speaking of the literary output about Pula and written in Pula, an important and indicative fact must be mentioned. The written word in Pula has always been created in various languages, various alphabets have been used, authors were or are members of various nationalities and cultures. It is a peculiarity of literary Pula and its authors. Discussing this fact would require a separate paper and we are going to mention only a few aspects of the linguistic dimension of Pula's literature and writers. With Croatian authors one can notice a presence of multilingualism and hybridity whose context can be found in Pula's multilingual culturological situation - a limes microspace, thus becoming the source of linguistic, sociolinguistic, psycholinguistic, stylistic and culturological analyses. Another aspect to be emphasized is foreign (if this attribute is adequate for the bordering and fluid area of the Istrian peninsula) literary dignitaries who happily visited the heartshaped peninsula or worked and created in Istria: Dante Alighieri, Thomas Mann, Hermann Bahr, Paula von Preradović (Austrian writer, granddaughter of the Croatian writer Preradović; she composed the lyrics for the national anthem of Austria), Ivan Cankar, Karl Kraus, James Joyce, Franz Karl Ginzkey, and Croatian

${ }^{10}$ Zvane (Ivan) Črnja (Črnjeni near Žminj 1920 - Zagreb 1991) poet, prosaist, essayist, culturologist, screenwriter, dramaturge and film expert, journalist, publicist, polemicist and publisher. Črnja is one of the most prominent names Istria gave to Croatia in the $20^{\text {th }}$ century. Pen names: Osip Suri, Barba Zvane, Filus. He also wrote books for children and the young, e.g.. Priča o zemlji ilirskoj, an illustrated poem for children, 1953., Priča o zemlji Iliriji, a poem for children and the young, 1981 and 1994.

${ }^{11}$ The event is closely linked to the Association Udrugom Sa(n)jam knjige u Istri Dreamlike Book Fair in Istria, while the Sa(n)jam - Dreamlike was founded by Boško Obradović, Magdalena Vodopija, Tereza Pulja and Zoran Vodopija under the auspices of the cult bookshop Castropola in Pula. The Association's goal is to connect and present artists and scientists of the Mediterranean, Central Europe and South-Eastern Europe through strong cultural projects, in particular those linked to books. Moreover, the Association established the Istrian Book Centre Histrica Nova, the multidisciplinary Polis - Adriatic - Europe Festival and the Monte Librić Children's Book Festival.

${ }^{12}$ Indicative are, in relation to the contents of this paper, the central topics of the Essay Days. In 2003 the topic was Identity and Globalisation, in 2004 City - Essay (with introductory programme "Joyce in Pula") and in 2007 The Province. 
writers Antun Šoljan and Miroslav Krleža. (Arambašin-Slišković, 1996) Certainly, the important and unavoidable contribution of Istrian Italians must not be forgotten, just to mention a few: Ligio Zanini, Eros Sequi, Fulvio Tomizza, Lucifero Martini, Giovanni Santin, Giusto Curto, Mario Schiavato, Loredana Bogliun, Nelida Milani, Umberto Matteoni. Their creative endeavour and literature in various languages as well as their pervasions, greatly contributed to the overall (multi)cultural identity of Istria, which (still) requires further studies and research.

\section{Conclusion}

To belong to an environment, by working in it and/or (just) living in it, means to become a part of its culture, written culture included. Each intellectual, and a teacher definitely is one, is part of a cultural matrix of an environment. In this context, we were interested in the written literary and authors' production, considered in a wider culturological sense which includes records and testimonies on a concrete environment - the City of Pula. The city developed among various geographical, political, culturological and strategic influences and recorded a complex and intriguing history. This history is written about by writers who reinterpret and re-construct selected historical events of Pula, making literary and artistic artefacts - as a kind of answers to this and to such history. As such they are recognized as part of a locally focalized literature written by Central Europeans and tending to re-study the history based on the complexity of all its dimensions. These writers, therefore, like other Central European authors, do not subvert the authority of history, do not oppose its objectivity nor supplement it. Their works are parallel narratives which implicitly point to those aspects that history excludes, neglects, omits by seeking to form general(ised) pictures of the past. Moreover, they point to the unsustainability of any exclusivity and privileged status of only one undeniable truth Even when the truth is literary and artistic.

Living and creating in a liminal space, at the edge of Central Europe, which is (was) being permanently colonised and appropriated, the authors of Pula wrote works which are not a one-dimensional presentation of history and space. In their opus an internal communication voice is articulated and speaks about the empathic with human experience, about centres of identification, about decisions and choices, about "insurrections" as an alternative to what was (already) recorded, without seeking to proclaim the own account as the only valid and undeniable one. All this proves that being on the border means becoming reconciled with it. These authors wipe out the borders between writing history and writing literature. In their opening to pluralisation and in recognition of the coexistence of a number of models and explanations, and in the irony of disclosing every totalitarian position, we can recognize a specific aspect of scepticism intrinsic to the sceptic central Europe which has long been doubting the sense of teleological history.

Can we call ourselves educators of young generations or their teachers if we do not know the cultural achievements of the environment we belong to? 
To what extent does permanent education of teachers comprise also his/her fostering of personal insight into the art of the written word, particularly in the milieu where he/she realises his/her honourable life vocation.

Who is helping him/her and how much? What sources of information are available to him/her? Does the educational system do enough in this sense?

We hope that this paper is a contribution to (permanent) informing and heightening of awareness of (future) teachers about the literary life and heritage of the environment where they live and work, as this will largely contribute to the quality and achievements of their work with students.

\section{Bibliography}

ARAMBAŠIN-SLIŠKOVIĆ, T. (1996), Koliki su te voljeli, moja Pulo, Zagreb: Nakladni zavod Matice hrvatske, etc.

BALOTA, M. (2005), Puna je Pula, Pula: Amforapress

FLAKER, A. (1986), Stilske formacije, Zagreb: Sveučilišna naklada Liber

KRIŽMAN, M. (1979), Antička svjedočanstva o Istri. Izbor iz djela, izabrao, preveo i priredio Mate Križman, Pula - Rijeka: Čakavski sabor - Pula, Otokar Keršovani - Rijeka, Istarska naklada - Pula, Edit - Rijeka

KUNDERA, M. (1985), Tragedija Srednje Europe, (U: Gordogan, Zagreb, 7, no.17-18, pp. 289-305

MAIR, A.W. (1921), Callimachus and Lycophron with an English translation by A.W. Mair, D.Litt., London: W. Heinemann, New York: G.P. Putnam, 1921, p. 301, Fragment 1 (103))

NAČINOVIĆ, D. (2003), Pula sa starih razglednica, Pula: C.A.S.H.

PETKOVIĆ, N. (2003), Srednja Europa - zbilja - mit - utopija: postmodernizam, postkolonijalizam i odsutnost autentičnosti, Rijeka: Adamić

RAKOVAC, M., (1995), Riva i druži, Pula, C.A.S.H.

VUKUŠIĆ, S. (1997), Duh u kamenu, Zagreb: Naklada društva hrvatskih književnika, Nakladni zavod Matice Hrvatske književnika

VUKUŠIĆ, S. (2003), Zvijezde nad Gočanom, Pula: Istarski ogranak, Društvo hrvatskih 
Metodički obzori 7(2012)1

Pregledni rad

UDK: 821.163.42(497.5Pula):371.12.011.3-051]:659

Received: 17. 7. 2010.

\section{PULA I KNJIŽEVNOST \\ (Oris jedne moguće dijakronije)}

dr.sc.Vjekoslava Jurdana,

Odjel za odgojne i obrazovne znanosti

Sveučilište Jurja Dobrile - Pula (Hrvatska)

e-mail: vjekoslava@hi.t-com.hr

Korina Fabris, apsolventica učiteljskoga studija

Sveučilište Jurja Dobrile - Pula (Hrvatska)

e-mail: kfabris@gmail.com

Karmen Legović, apsolventica učiteljskoga studija

Sveučilište Jurja Dobrile - Pula (Hrvatska)

e-mail: karmen.legovic@gmail.com

S a ž e t a $k$

U radu se polazi od zadaće učitelja da promiču književno nasljeđe sredine u kojoj žive/i/ili rade. Kako bi se to ostvarilo, potrebno je da se učitelji/ce permanentno informiraju o književnim dosezima konkretne sredine.

Autorice nude jedan mogući oris književne dijakronije pulske sredine, ističući njegove bitne točke, ističući potrebu za daljnja permanentna slaganja toga bogatoga mozaika.

Ključne riječi: književnost, Pula, povijest, učitelj/ica, recepcija književnoga djela 